\title{
GENDER DIFFERENCES IN TEACHERS' BELIEFS AND PRIMARY SCHOOL CHILDREN'S ACHIEVEMENT IN MATHEMATICS
}

\author{
Inger Throndsen, Are Turmo \\ University of Oslo, Norway \\ E-mail: inger.throndsen@ils.uio.no, are.turmo@ils.uio.no
}

\begin{abstract}
The main purpose of this study was to examine differences in male and female teachers'beliefs about their math instruction, and the relationship between boys and girls math achievement and teachers' beliefs. The samples were primary mathematics teachers $(N=521)$ and Year 2 and Year 3 students $(N=9980)$ from 127 schools. A questionnaire was used to examine primary math teachers' goal structure for students, approaches to instruction, and personal teaching efficacy. Students' math achievement was assessed by national diagnostic math tests. The teachers were generally oriented towards mastery goals and mastery approaches to instruction, and reported high personal teaching efficacy. However, female teachers report somewhat higher levels of mastery goal structure for students and mastery approaches to instruction, while male teachers report a somewhat higher level of performance approaches to instruction. Positive relations between students' math performance and teachers 'mastery orientation, mastery approaches to instruction, and teaching efficacy were also found. These relationships were somewhat stronger for girls than for boys. In conclusion, the relationship between teachers' beliefs and students' performance were different for male and female teachers, respectively. In future studies qualitative research methods should be included.
\end{abstract}

Key words: mathematics achievement; primary school; teachers'beliefs.

\section{Introduction}

\section{Background}

An extensive body of research on gender differences in mathematics has been dealing with student mathematics learning. Less attention has been paid to gender differences in teachers' beliefs, the relationship between teacher beliefs and gender, and male and female students' math performance. It is widely agreed that teachers are among the most, if not the most significant factors in students' learning (Cochran-Smith \& Zeichner, 2005). In the study of gender issues it appears that teachers' beliefs are an important variable. According to Fennema (1990), insights into teachers' beliefs may lead to deeper understanding of gender differences in mathematics. For example, male and female teachers may hold different beliefs about students' math learning. This may have effect on their instructional practices, which in turn can affect students' beliefs and math achievement. Differences in teachers' instructional approaches may also have differential effects on male and female students, respectively. It is also a question whether the combined effect of teacher beliefs and gender may influence girls' and boys' math learning differently.

In a recent study based on classroom observations in Norwegian schools (Years 3, 6, 
PROBLEMS

OF EDUCATION

IN THE $21^{\text {st }}$ CENTURY

Volume 39, 2012

160 in different subject domains, including mathematics (Haug, 2010). However, teachers' beliefs related to students' learning and development have obtained little attention (Buehl \& Alexander, 2009). The present study uses goal orientation theory for examining gender differences in teachers' beliefs about their instruction in mathematics, the relationship between teacher beliefs and gender, and student math achievement and gender (the term "gender" rather than the term "sex" is used through out the article, with gender referring to biological sex). Many researchers assume that school children show the most positive motivation and learning patterns when their classroom setting emphasize mastery, understanding, and improving skills and knowledge (Meece, Anderman \& Anderman, 2006). In contrast, when classroom environments focus on demonstrating high competence, research suggests that under these conditions many students experience a decrease in motivation. From a goal orientation perspective teachers' beliefs and instructional practices are assumed to influence students' goal orientations.

Goal orientation theories focus students' intentions or reasons for engaging, choosing, and persisting at different learning activities, and were developed to explain students' learning and performance on academic tasks (Schunk, Pintrich \& Meece, 2008). According to Ames (1992, p. 261), goal orientation represents an integrated pattern of beliefs that leads to "different ways of approaching, engaging in, and responding to achievement situations". The goal orientation research has suggested that there are two general goal orientations concerning the reasons students are pursuing when approaching and engaging in a task. Students can adopt a mastery goal orientation or a performance goal orientation (Ames, 1992; Anderman \& Midgley, 2002; Maehr \& Zusho, 2009; Schunk et al., 2008). Students, who adopt a mastery goal orientation, focus on learning, developing new skills, and to improve their competence. It is important for them to gain understanding or insight, and success is evaluated in terms of self-improvement. In contrast, a performance goal orientation represents a focus on demonstrating high ability relative to others, trying to outperform other students, and seeking public recognition of one's performance. Success is evaluated from doing better than others. It is assumed that mastery goal orientations are positively related to a number of motivational and cognitive processes and behaviour outcomes (Ames, 1992; Malmberg, 2008; Meece, 1994; Pintrich \& De Groot, 1990; Wolters, Yu \& Pintrich, 1996). In contrast, performance goal orientations are assumed to produce negative effects. It appears that having a higher mastery goal orientation and a lower performance orientation results in the best level of motivational and cognitive engagement (Meece \& Holt, 1993).

\section{Teacher's Beliefs and Instructional Approaches}

Goal orientation theorists argue that students' personal goal orientation is influenced by the teacher's instructional practices in the classroom. The fundamental assumptions behind the research on teachers' beliefs are that teacher behaviours are substantially influenced and even determined by teacher beliefs. These behaviours, in turn, impact upon student beliefs and behaviour (Li, 1999). Teachers may have mastery and performance goals for their students, and that they tend to utilize teaching strategies that match their own motivational orientation and beliefs. In other words, teachers' goal orientations both affect and reflect their instructional practices. Thus, classroom goal structures are generally viewed as precursors of students' personal goal orientation, and it is assumed that teachers through their use of instructional strategies create different goal structures in the classroom. For example, an evaluation practice dominated by social comparison among students can foster a performance orientation in students. Teachers who emphasize performance-oriented practices also tend to point out ability differences, to show the work of the best students as examples for others, and to use competitive 
instructional methods. On the other hand, focus on individual improvement, and feedback that communicates that mistakes are a part of learning and that effort is important for learning will help students adopt a mastery goal orientation. Teachers who engage in mastery-oriented instructional practices also tend to create learning environments where all students can feel that they succeed and feel a sense of mastery and improvement. Such classrooms emphasize effort, improvement, and challenges (Ames, 1992; Anderman, Eccles, Yoon et al., 2001; Maehr \& Zusho, 2009; Schunk et al., 2008). Thus, teachers' instructional practice can be an important contributor to students' adoption of goal orientation.

Research findings show that students' personal goal orientations correspond with their subjective perceptions of the classroom goal structure. For example, Friedel and colleagues examined Year 7 students' perceptions of the achievement goals teachers emphasize for them in mathematics, and the relation of these goals to children's personal goal orientation. Results show that students' perceptions of teacher mastery and performance goal emphasis predicted students' personal goals (Friedel, Cortina, Turner \& Midgley, 2007). They also found that children's personal goals mediated the relation between perceived teacher goal emphasis and students' efficacy beliefs. Anderman et al.s (2001) study showed that performance-oriented instructional strategies (e.g., pointing out the work of the best students as examples to others) was related to lower levels of student mastery goal in Years 3, 4, and 6. It also had negative effects on students' valuing of academic subjects. Thus, the goals teachers emphasize through their instruction practices may have important consequences for students' motivation and cognitive processing. However, the expected positive relation between mastery goals and performance has not been consistent (Meece et al., 2006). There may also exist grade level differences in teachers' goal orientation. Anderman et al. (2001) found that teachers of students in higher grade levels reported using performance oriented instructional practices more than did teachers of students in lower grades.

\section{Research on Teacher and Student Gender}

Unlike the interest in gender differences in students' math learning and achievement, relatively little focus has been on teacher gender, for example whether it makes a difference for student achievement if a teacher is male or female. So far, no typical pattern can be drawn from the research literature on the effects of teacher gender on students' math achievement (Li, 1999). Another gender-related question is whether boys fare best in classes taught by male teachers, while girls fare best in classes taught by female teachers. In the research literature on the significance of teacher gender on student achievement, two competing models have been used (Martin \& Marsh, 2005). The first model can be considered a gender-stereotypic model, which suggests that boys do better in classes taught by males and girls do better in classes taught by females. The second model can be considered a gender-invariant model which suggests that boys' and girls' achievement does not significantly vary as a function of their teacher's gender. Martin \& Marsh (ibid.) studied the impact of student gender, teacher gender, and their interaction on academic motivation and engagement for junior and middle high school students (Years 8 and 10) in mathematics classrooms. They found that girls rate their relationships with female teachers better than they rate their relationships with male teachers. They also registered that boys and girls are no more engaged in classes taught by males than they are in classes taught by females, which support the gender-invariant model. Finally they report that boys did not fare any better with male teachers than female teachers. This finding runs counter to the gender-stereotypic model. These findings can, however, not be generalized to younger children. Martin \& Marsh conclude that similar research is needed at lower school levels.

Li's (1999) extensive review of the research literature dealing with gender differences 
PROBLEMS

OF EDUCATION

IN THE $21^{\text {st }}$ CENTURY

Volume 39, 2012

162

indicate that more positive attitudes towards mathematics were demonstrated by female students taught by female teachers. Male students tend to give male teachers higher ratings, while female students favour female teachers. In other words, when a teacher-students gender interaction with respect to student rating of teachers is present, it most often appears to reflect a same-gender preference; i.e. supporting the gender-stereotypic model. Unfortunately detailed information about the age of the students in the different studies is lacking. Concerning the effects of teacher gender on students' mathematics achievement, it seems that no typical pattern can be drawn from the literature since the research findings are inconsistent. Li (ibid.) argue that some of the conflicting findings may be due to cultural differences rather than gender differences. Correlation between teacher gender and gender differences in students' math achievement were mostly observed in areas other than Western countries. Gender differences in teacher-student interaction in mathematics classrooms have also been investigated. Li's review shows that teacher-male student interactions are more frequent than teacher-female student interactions. The gender of the teacher does not seem to affect that teachers (both male and female) tend to interact more often with male students. However, one important teacher gender distinction is that female teachers tend to be more student-centred and supportive of students than male teachers. Female teachers also appear to use class discussion more frequently and encourage collaboration. Li conclude that the relationship between gender differences in teachers' beliefs and gender differences in their classroom instructions in mathematics need to be explored.

\section{Aims of the Study and Research Questions}

Research in mathematics education exploring issues related to gender differences in teachers' beliefs in mathematics is sparse (Li, 1999). According to Butler \& Shibaz (2008) a systematic, theory-driven research on teachers' motivational beliefs is lacking, although the classroom may be considered as an achievement area also for teachers. Goal orientation theory may provide a useful framework for conceptualizing qualitatively differences in teachers' motives for teaching and is highly relevant for understanding teachers' instruction. Thus, in the present study the goal orientation perspective is extended by taking into account teacher and student gender. Male and female teachers may hold different beliefs about math instruction and student learning. Therefore, the first objective for the present study is to investigate primary male and female teachers' perceptions and beliefs about their personal goal structures, approaches to instruction, and personal teaching efficacy in mathematics.

Issues related to teacher gender and student gender in teaching and learning mathematics are also unclear. A second aim is therefore to examine the relation between the three aspects mentioned above (i.e. teachers' achievement goals for students, their approaches to instruction, and their personal teaching efficacy), teacher and student gender, and student achievement. Prior research within the goal orientation framework has primarily been directed towards older students. Thus, there is also a lack of studies focusing on classroom settings with young students. At the early elementary level most students have spent their time in self-contained classrooms with just one teacher or one team of teachers. This creates a unique opportunity to study the relationship between teacher's beliefs and gender and students' achievement and gender. The following research questions will be addressed:

1. Are there differences in how male and female primary math teachers report goal structures for students, approaches to instruction and personal teaching efficacy?

2. Are there empirical relationships between male and female students' math performance and male and female teachers' reported goal structures, approaches to instruction and personal teaching efficacy? 


\section{Methodology of Research}

\section{Sample}

In the present study, all Norwegian primary schools with more than 50 students in average per grade level were invited to submit data. In total, 262 schools were invited to submit student results. In addition, the teachers of mathematics in Year 2 (7 year olds) and Year 3 (8 year olds) were asked to respond to a questionnaire. 127 of the invited schools returned both teacher and student data. Schools not wanting to participate typically stated that they lacked capacity due to participation in other surveys or having to fulfil other administrative tasks. The data was collected in May and June 2009. In total, data from 521 teachers and 9980 students was received, i.e. approximately 4 teachers and 79 students per responding school. 58 percent of the responding teachers teach in Year 2.

In Norway the primary school level consists of Years 1 (6 year olds) to 7 (13 year olds). The primary (and lower-secondary) level is highly comprehensive; there is no explicit streaming of students based on abilities into different schools. Almost all students attend the school which are the nearest to their home. It is neither allowed to have stable groupings within schools based on students' abilities, interests etc. The majority of teachers at the primary level are trained as generalist teachers and are accordingly licensed to teach all subjects in Years 1 to 7.

\section{Instruments and Implementation}

Since it is not recommended to administer questionnaire to students in Years 2 and 3, a math test was used as an outcome measure. National diagnostic tests, constructed to measure students' basic numerical understanding, understanding of mathematical operations, and computational skills, were utilized. In the test development process, it was also necessary to construct a theoretical framework which described the competency aims more precisely (Alseth, Throndsen \& Turmo, 2008; Alseth, Throndsen \& Turmo, 2009). This framework builds on extensive international research, as many studies have been conducted with the aim of describing students' competencies within these areas (e.g. Ahlberg \& Hamberg, 1995; Anghileri, 2000; Bobis, Clark, Clark et al., 2005; Carpenter, Fennema, Franke et al., 1999; Denvir \& Brown, 1986a; 1986b; Jones, Thornton, Putt et al., 1996). The conceptualisation of the competencies is relatively consistent in this research literature.

Trial versions of the diagnostic tests were piloted, and the final tests which were administered in spring 2009 showed reliabilities of 0.96 (Year 2) and 0.97 (Year 3), measured by Cronbach's alpha (see Crocher \& Algina, 1986). Both tests serve as national diagnostic tests, and they are mandatory for all Norwegian school children at the end of $2^{\text {nd }}$ and $3^{\text {rd }}$ school year. The total numbers of score points in the tests are 74 and 85 , respectively. The student tests were marked by the teachers based on detailed coding guides, and the results (score per test page and total score) were submitted. These results were then manually typed into the statistical software used for analysis.

The Patterns of Adaptive Learning Scales (PALS) was used as a starting point in the development of teacher questionnaire. PALS (Midgley et al., 2000) use goal orientation theory as a framework. To validate the scales Midgley et al. conducted confirmatory factor analysis, and the analysis confirmed the expected model (goodness of fit indices suggested that the model fits the data well) (Midgley, Kaplan, Middleton et al., 1998). The teacher scales in PALS consist of three parts; Goal structure for students, Approaches to instruction, and Personal teaching efficacy. The scales were translated into Norwegian. Since Migdley et al. had phrased the items in terms of class or schoolwork in general, the items were adapted to measure domain-specific 
PROBLEMS

OF EDUCATION

IN THE $21^{\text {st }}$ CENTURY

Volume 39, 2012

164 goals and perceptions by explicitly tailoring the items to mathematics instruction. For example, "Students are told that making mistakes is $\mathrm{OK}$ as long as they are learning and improving" was adapted to "Students are told that making mistakes in mathematics is OK as long as they are learning and improving". A seven point Likert scale ranging from totally disagree (1) via neutral (4) to totally agree (7) was applied. The teacher questionnaire was piloted and revised before the main data collection. The teachers were also asked to respond to selected background questions on professional experience, educational background etc. They responded to the questionnaire in paper version, and the data were registered manually into the statistical software used for analysis. Table 1 presents the constructs with example items and reliabilities.

In the questionnaire, selected background questions were also asked of the teachers, e.g. age, gender, experience as teacher, education in mathematics and in mathematics education, future career perspectives etc. These variables were used as control variables in the analysis.

Table 1. Constructs with example items.

\begin{tabular}{|l|c|c|c|}
\hline \multicolumn{1}{|c|}{ Construct } & $\begin{array}{c}\text { Number of } \\
\text { items }\end{array}$ & Example item & Cronbach's alpha \\
\hline $\begin{array}{l}\text { Mastery Goal Structure for } \\
\text { Students }\end{array}$ & 6 & $\begin{array}{c}\text { Students are told that making mis- } \\
\text { takes in math classes is OK as long } \\
\text { as they are learning and improving. }\end{array}$ & 0.72 \\
\hline $\begin{array}{l}\text { Performance Goal Struc- } \\
\text { ture for Students }\end{array}$ & 5 & $\begin{array}{c}\text { Students who do the best work in } \\
\text { math are pointed out as an example } \\
\text { to others. }\end{array}$ & 0.73 \\
\hline $\begin{array}{l}\text { Mastery Approaches to } \\
\text { Instruction }\end{array}$ & 6 & $\begin{array}{l}\text { During math class, I often provide sev- } \\
\text { eral different activities so that students } \\
\text { can choose among them. }\end{array}$ & 0.72 \\
\hline $\begin{array}{l}\text { Performance Approaches } \\
\text { to Instruction }\end{array}$ & 6 & $\begin{array}{c}\text { I encourage students to compete with } \\
\text { each other in mathematics. }\end{array}$ & 0.74 \\
\hline $\begin{array}{l}\text { Personal Teaching Ef- } \\
\text { ficacy }\end{array}$ & 4 & $\begin{array}{l}\text { I am good at helping all the students } \\
\text { in my math classes make significant } \\
\text { improvement. }\end{array}$ & 0.75 \\
\hline
\end{tabular}

Analysis

The analysis was conducted using the statistical software SPSS 16. Each teacher's "generated learning outcome" was then defined as the performance of the class in which the teacher has the main responsibility of teaching mathematics. This information was asked for in the questionnaire. If the teachers stated that they had the main responsibility in several classes, the mean value of these classes was calculated. Some very few teachers without main responsibility in any class were excluded from the analysis.

Effect sizes are used in the analysis to express the differences between groups. Effect sizes are expressed as Cohen's $d$ (Cohen, 1992) where M and S denote the means and standard deviations of two arbitrarily groups being compared: Cohen's $\quad d=M_{1}-M_{2} / \sigma_{\text {pooled }}$ where $\sigma_{\text {pooled }}$ $=\sqrt{ }\left[\left(\sigma_{1}^{2}+\sigma_{2}^{2}\right) / 2\right]$

\section{Results of Research}

Table 2 shows mean values for female and male teachers for the constructs presented in table 1. Table 2 shows that female teachers report somewhat higher levels of mastery goal structure for students and mastery approaches to instruction, while male teachers report 
Inger THRONDSEN, Are TURMO. Gender Differences in Teachers' Beliefs and Primary School Children's Achievement in Mathematics

$\mid$\begin{tabular}{l} 
PROBLEMS \\
OF EDUCATION \\
IN THE 21 $1^{\text {st }}$ CENTURY \\
Volume 39, 2012 \\
\hline 165
\end{tabular}

a somewhat higher level of performance approaches to instruction. However, none of the differences between female and male teachers are statistically significant, partly due to the relatively small sample size for male teachers.

Table 2. Mean values for female and male teachers ( $1=$ totally disagree, $7=$ totally agree). Positive effect sizes in favour of female teachers.

\begin{tabular}{|l|c|c|c|}
\hline & $\begin{array}{c}\text { Mean female } \\
\text { teachers } \\
N=458\end{array}$ & $\begin{array}{c}\text { Mean male } \\
\text { teachers } \\
N=62\end{array}$ & Cohen's d \\
\hline 1. Mastery Goal Structure for Students & 5.64 & 5.48 & 0.22 \\
\hline 2. Performance Goal Structure for Students & 3.42 & 3.46 & -0.03 \\
\hline 3. Mastery Approaches to Instruction & 5.68 & 5.52 & 0.23 \\
\hline 4. Performance Approaches to Instruction & 3.08 & 3.28 & -0.19 \\
\hline 5. Personal Teaching Efficacy & 5.20 & 5.11 & 0.11 \\
\hline
\end{tabular}

Table 3 shows the empirical relationships between the five teacher constructs and mean test scores for girls and boys in the corresponding classes. Separate results for female and male teachers are also displayed. Table 3 shows positive relationships between student scores and the constructs teacher mastery goal structures, mastery approaches to instruction and personal teaching efficacy in the group of all teachers. These relationships tend to be somewhat stronger for female students than for male students, and the relationships for female students are also statistically significant $(p<0.05)$.

The empirical findings in the group of male teachers, however, deviate clearly from the overall picture. Female students of male mathematics teachers with a strong emphasis on performance approaches to instruction tend to score somewhat higher on the tests. A corresponding tendency, however, is not established for male students. Furthermore, male students of male teachers with a high reported personal teacher efficacy tend to score lower on the tests, and the same tendency is found regarding performance goal structures for students. However, none of these tendencies are statistically significant.

\section{Table 3. Empirical relationships between teacher constructs (see table 1) and students' math achievement (girls and boys separately).}

\begin{tabular}{|l|c|c|}
\hline & \multicolumn{1}{|c|}{$\begin{array}{c}\text { Correlation with } \\
\text { Mean Score Girls }\end{array}$} & $\begin{array}{c}\text { Correlation with Mean } \\
\text { Score Boys }\end{array}$ \\
\hline All teachers $(N=521)$ & & 0.11 \\
\hline 1. Mastery Goal Structure for Students & $0.14^{*}$ & -0.02 \\
\hline 2. Performance Goal Structure for Students & 0.02 & 0.10 \\
\hline 3. Mastery Approaches to Instruction & $0.15^{*}$ & -0.01 \\
\hline 4. Performance Approaches to Instruction & 0.00 & 0.09 \\
\hline 5. Personal Teaching Efficacy & $0.16^{*}$ & 0.13 \\
\hline Female teachers $(N=458)$ & & 0.00 \\
\hline 1. Mastery Goal Structure for Students & $0.15^{*}$ & 0.12 \\
\hline 2. Performance Goal Structure for Students & 0.02 & -0.01 \\
\hline 3. Mastery Approaches to Instruction & $0.17^{*}$ & 0.13 \\
\hline 4. Performance Approaches to Instruction & -0.02 & -0.02 \\
\hline 5. Personal Teaching Efficacy & $0.19^{*}$ & -0.14 \\
\hline Male teacher (N=62) & & -0.02 \\
\hline 1. Mastery Goal Structure for Students & 0.02 & 0.02 \\
\hline 2. Performance Goal Structure for Students & 0.02 & -0.25 \\
\hline 3. Mastery Approaches to Instruction & 0.03 & 0.15 \\
\hline 4. Performance Approaches to Instruction & -0.05 & \\
\hline 5. Personal Teaching Efficacy & & \\
\hline
\end{tabular}

Note. ${ }^{*} \mathrm{p}<0.05$. 


\section{PROBLEMS \\ OF EDUCATION \\ IN THE $21^{\text {st }}$ CENTURY \\ Volume 39,2012 \\ 166 Discussion}

In the present study gender differences in primary math teachers' personal goal orientations for teaching, instructional practices, and personal teaching efficacy were examined. The relationships between these constructs and student mathematics performance, i.e. male and female students' achievement, respectively, were also investigated. To date, most research within the goal orientation framework has focused older students (i.e., middle and high school levels), and there has been little systematic research on teachers' beliefs. Thus, the knowledge about relations between primary teacher beliefs and practices in mathematics and student achievement is sparse. There is limited knowledge about gender differences in teacher beliefs and the influence teacher gender may have on girls' and boys' math learning.

The present study shows relatively high values for male and female teachers' mastery goal structure for students and mastery approaches to instruction, while performance goal structure for students and performance approaches to instruction had a relatively low average in both groups. This result indicates that Norwegian math teachers in Years 2 and 3 is generally more oriented towards mastery goals than performance goals for their students, and that they are inclined to utilize instructional approaches creating learning environments that foster students' mastery orientation. In other words, students at the lowest grade levels are more strongly exposed to instructional strategies in mathematics that reflect a mastery orientation to learning. Prior research has shown grade level differences in classroom goal structures, i.e., teachers of students in higher grade levels reported using performance oriented practices more than did teachers of students in the lower grades (Anderman et al., 2001; Midgley et al., 2000). This may indicate that older students are more exposed to performance oriented instructional practices. In the present study a comparison of the different construct measurements shows some teacher gender differences. While female teachers report higher levels of mastery goal structure for students and mastery approaches to instruction, male teachers report a somewhat higher level of performance approaches to instruction. However, a significant limitation of the study is the relatively low number of male mathematics teacher in our sample, which reflects that the vast majority of teachers at this level are female.

Over the past decades there has been a great deal of research investigating teacher and student gender differences in aspects related to mathematics. For example, considerable research has examined gender differences in teachers' perceptions of their students' abilities. Early studies suggested that teachers have higher achievement expectations for boys than for girls, especially in male gender-typed domains like mathematics (Li, 1999; Meece, Glienke \& Askew, 2009). However, gender differences in teacher expectancies seems to depend on grade level and appear to be more pronounced at higher grade levels. According to Turner \& Meyer (2009), students' beliefs about why they are motivated to learn mathematics are connected to what they are learning (i.e., mathematical knowledge and processes), how they are learning (i.e., instruction, interaction), and where they are learning (i.e., classroom culture). Therefore the learning environment teachers create through their instructional practices and interactions with the students are essential sources for student motivation. For example, there is some evidence to suggest that girls respond more negatively than boys to competitive teaching conditions, i.e. classroom environments that focus on demonstrating high competence. Other research suggests that girls initiate more interactions with teachers and report higher achievement expectations for mathematics in classes where individualized or cooperative learning is the primary mode of instruction (Meece et al., 2009).

In the reported study, positive relationships were found between students' math achievement and the following teacher constructs: mastery goal structure for students, mastery approaches to instruction, and personal teaching efficacy. These relations tend to be somewhat stronger for female teachers-female students than for female teachers-male students. This 
finding may indicate that the learning environment may influence girls and boys math learning somewhat differently, and that girls achieve better under conditions dominated by mastery approaches to learning. Thus, this result supports to some degree the gender-stereotypic model, i.e. that teacher goal structures have a stronger impact on girls than on boys in classes taught by females. In Li's (1999) extensive review of the research literature dealing with gender differences, no typical pattern was found concerning the effects teacher gender may have on students' mathematics achievement. In other words, it may be the nature of pedagogy that is influential on girls' and boys' performance and not the gender of the teacher responsible for the instruction. Further analyses of our data show only neglectable differences in math performance between boys taught by male and female teachers, respectively, and the same is found for girls. According to goal orientation theory, the classroom goal structure and the instructional strategies teachers use are precursors of students' personal goal orientation, and students' perceptions of the learning environment are crucial for the goal orientation they adopt (Anderman \& Midgley, 2002).

Li's (1999) review shows that female students favour female teachers, while male students tend to give male teachers higher ratings. Li also found that female students taught by female teachers demonstrated more positive attitudes towards mathematics. In the present study female teachers report higher levels of mastery goal structure for students and mastery approaches to instruction than male teachers. Therefore, it may be the combined effect of teacher gender and teacher beliefs and practice that have had a positive influence on the girls' math learning. Another interesting result from the present study is that the relationships between the teacher constructs and student math performance are clearly different for male teachers compared to female teachers. The relationships between male teacher beliefs and student achievement clearly deviate from the overall picture. It is, however, not reasonable to draw any definite conclusions from these findings because of the relatively small sample size for male teachers, and the number of male teachers in the study is too low to make generalizations. However, these findings may be a starting point for more in-depth studies of male primary math teacher's goal structures and their interaction patterns with students. The results indicate that male teachers clearly deviate from female teachers at the primary level in these respects.

In prior research within the goal orientation framework the expected positive relation between mastery goal orientation and student achievement has not been consistent. One possible explanation may be that various measurements have been utilized to assess student achievement. Meece et al. (2006) argue that most achievement measurements are not designed to assess the students' deep understanding of a content area. In the present study, students' mathematical competency in Year 2 and Year 3 was measured by tests of high quality, specially designed to assess basic numerical understanding, understanding of mathematical operations, and computational skills.

Self-efficacy theory has been widely used to understand gender differences in student motivation and achievement. Much of this research has focused on academic areas that are traditionally gender-typed as male or female domains of achievement. For example, numerous studies document that boys tend to report higher self-efficacy beliefs than girls about their performance in math, even though corresponding gender differences in male and female students' achievement have not been found (Schunk et al., 2008).

In the present study a relatively high value was registered for personal teaching efficacy for both male and female teachers, with a slight difference in favour of the female teachers. This finding indicates that Norwegian primary math teachers in general believe they contribute significantly to the academic progress for their students and that they can effectively teach all students. In comparison Midgley et al. (2000) registered a slightly lower teaching efficacy value among math teachers in grade 9. This may indicate grade level differences in teaching efficacy, with higher efficacy beliefs among teachers at lower grade levels. This may be due to the fact 
PROBLEMS

OF EDUCATION

IN THE $21^{\text {st }}$ CENTURY

Volume 39, 2012

168

that academic content grows more complex and difficult. Therefore teachers' sense of efficacy for subject teaching may become increasingly important during the lower secondary grades and beyond. However, several surveys show that teachers' efficacy beliefs increase with experience (Hoy, Hoy \& Davis, 2009). In the present study a significant positive relation is registered between female teachers' efficacy beliefs and female students' math achievement, while the relationship between male teachers' beliefs and student performance deviates from this pattern. In fact, boys taught by male teachers with high personal teaching efficacy perform poorer. As mentioned earlier, the results related to the male teachers in this study may be due to the relatively small sample size for male teachers. According to social cognitive theory, teachers' personal efficacy beliefs influence the same types of activities that student self-efficacy affects (Bandura, 1997). While teachers high on teaching efficacy believe they can enact certain teaching strategies and have effect on student learning and motivation, teachers with low efficacy tend to believe they cannot use these strategies and doubt whether they really can have an effect on students. Efficacy beliefs may also refer to perceptions of controllability. A teacher might have low teaching efficacy if (s) he believes that most students' learning is due to home or other factors outside of the teacher's control (Guskey \& Passaro, 1994). Teachers who feel control invest energy in their teaching, set optimal goals for their students, are persistent in their endeavours, and resilient when confronting obstacles (Malmberg, 2008).

\section{Conclusions}

Primary teachers may pursue different goal orientations in their teaching, and through their instructional practices they signal to students that the point of school work is to learn and progress, or to perform better. Several studies provide evidence that students adopt the goal orientation emphasized through teacher's use of instructional strategies, and the importance of students' perceptions of the learning environment is underlined. To date, the knowledge about teachers' beliefs and instructional practices in mathematics at the lowest primary grade levels is limited. In addition, studies focusing on differences in the learning environment created by male and female teachers through their use of teaching strategies are sparse. However, research findings show that female teachers tend to be more student-centred and supportive of students than male teachers. In the present study female teachers report somewhat higher levels of mastery goal structure for students and mastery approaches to instruction, while male teachers report a somewhat higher level of performance approaches to instruction. Positive relationships were also found between students' math performance and female teachers' mastery orientation, mastery approaches to instruction and teaching efficacy, respectively. These relations are somewhat stronger for girls than for boys. For the male teachers the relationships between the teacher constructs and student math performance are clearly different. The relatively small sample of male teachers constitutes a serious limitation for the interpretation of these findings. The gender differences that were registered may, however, serve as an interesting starting point for further research. In future studies qualitative research methods should be included, and female and male teachers' interaction with female and male students should be explored more closely.

\section{References}

Ahlberg, A., \& Hamberg (1995). 6-åringars förståelse av tal och räkning, Gøteborg: Göteborg universitetet. [Six years olds' conceptual understanding of number and computation. Gothenburg: University of Gothenburg].

Alseth, B., Throndsen, I., \& Turmo, A. (2008). Rapport fra kartleggingsprøver $i$ tallforståelse og regneferdighet for 2. årstrinn og Vg1. Oslo: Universitetet i Oslo [Report on the mathematics tests. Oslo: University of Oslo]. 
Inger THRONDSEN, Are TURMO. Gender Differences in Teachers' Beliefs and Primary School Children's Achievement in Mathematics

$\mid$\begin{tabular}{l} 
PROBLEMS \\
OF EDUCATION \\
IN THE 21 $1^{\text {st }}$ CENTURY \\
Volume 39, 2012 \\
\hline 169
\end{tabular}

Alseth, B., Throndsen, I., \& Turmo, A. (2009). Arsrapport: Kartlegging av tallforståelse og regneferdighet på 2. og 3. årstrinn. Oslo: Universitetet i Oslo [Year Report on the mathematics tests. Oslo: University of Oslo].

Ames, C. (1992). Classrooms: Goals, structures, and students motivation. Journal of Educational Psychology, 84, 261-271.

Anderman, E. M., Eccles, J. S., Yoon, K. S., Roeser, R., Wigfield, A., \& Blumenfeld, P. (2001). Learning to value mathematics and reading: Relations to mastery and performance-oriented instructional practices. Contemporary Educational Psychology, 26, 76-95.

Anderman, E. M., \& Midgley, C. (2002). Methods for studying goals, goal structures, and patterns of adaptive learning. In C. Midgley (Ed.), Goals, goal structures, and patterns of adaptive learning (1-20). Mahwah, NJ: Lawrence Erlbaum Associates.

Anghileri, J. (2000). Teaching Number Sense. London: Continuum.

Bandura, A. (1997). Self-efficacy: The exercise of control. New York: W.H. Freeman.

Bobis, J., Clarke, B., Clarke, D., Thomas, G., Wright, R., Young-Loveridge, \& Gould, P. (2005). Supporting teachers in the development of young children's mathematical thinking: Three large scale cases. Mathematics Education Research Journal, 16, 27-57.

Buehl, M. M., \& Alexander, P. A. (2009). Beliefs about learning in academic domains. In K.R. Wentzel \& A. Wigfield (Eds.), Handbook of motivation at school (479-501). NY: Routledge.

Butler, R., \& Shibaz, L. (2008). Achievement goals for teaching as predictors of students' perceptions of instructional practices and students' help seeking and cheating. Learning and Instruction, 18 (5), 453-467.

Carpenter, T. A., Fennema, E., Franke, M. L., Levi, L., \& Empson, S. B. (1999). Children's mathematics: Cognitively guided instruction. Portsmouth, NH: Heinemann.

Cochran-Smith, M., \& Zeichner, K. M. (2005). Studying teacher education: The report of the AE RAPanel on Research and Teacher Education. Wahwah: Lawrence Erlbaum.

Cohen, J. (1992). A power primer. Psychological Bulletin, 112, 155-159.

Crocker, L., \& Algina, J. (1986). Introduction to Classical and Modern Test Theory. Fort Worth, Texas: Harcourt Brace Jovanovich College Publishers.

Denvir, B., \& Brown, M. (1986a). Understanding of number concepts in low attaining 7-9 year $s$ in Mathematics, 17, 15-36.

Denvir, B., \& Brown, M. (1986b). Understanding of number concepts in low attaining 7-9 year olds: Part II. The teaching studies. Educational Studies in Mathematics, 17, 143-164.

Fennema, E. (1990). Teachers' beliefs and gender differences in mathematics. In E. Fennema \& G. C. Leder (Eds.), Mathematics and gender (169-187). New York: Teachers' College Press. Friedel, J. M., Cortina, K. S., Turner, J. C., \& Midgley, C. (2007). Achievement goals, efficacy beliefs and coping strategies in mathematics: The role of perceived parent and teacher goal emphases. Contemporary Educational Psychology, 32, 434-458.

Guskey, T. R., \& Passaro, P. D. (1994). Teacher efficacy: A study of construct dimensions. American Educational Research Journal, 31, 627-643.

Haug, P. (2010). Korleis kvinnelege og mannlege lærarar underviser [How female and male teachers teach]. Bedre skole, 4, 24-28.

Hoy, A. W., Hoy, W. K., \& Davis, H. A. (2009). Teachers' self-efficacy beliefs. In K. R. Wentzel \& A. Wigfield (Eds.), Handbook of motivation in school (627-653). New York: Routledge.

Jones, G. A., Thornton, C. A., Putt, I. J., Hill, K. M., Mogill, A. T., Rich, B. S. \& Zoest, L. R. van (1996). Multidigit number sense: A framework for instruction and assessment. Journal for Research in Mathematics Education, 27, 310-336.

Li, Q. (1999). Teachers' beliefs and gender differences in mathematics: a review. Educational Research, 41, 1, 63-76.

Maehr, M. L., \& Zusho, A. (2009). Achievement goal theory: The past, present, and future. In K. R. Wentzel \& A. Wigfield (Eds.), Handbook of motivation at school (77-104). NY: Routledge. 
PROBLEMS

OF EDUCATION

IN THE $21^{\text {st }}$ CENTURY

Volume 39,2012

170 Martin, A., \& Marsh, H. (2005). Motivating boys and motivating girls: Does teacher gender really make a difference? Australian Journal of Education, 49, 3, 320-334.

Malmberg, L. E. (2008). Student teachers' achievement goal orientations during teacher studies: Antecedents, correlates and outcomes. Learning and Instruction, 18 (4), 438- 452.

Martin, A., \& Marsh, H. (2005). Motivating boys and motivating girls: Does teacher gender really make a difference? Australian Journal of Education, 49 (3), 320-334.

Meece, J. L. (1994). The role of motivation in self-regulated learning. In D. H. Schunk \& B. J. Zimmerman (Eds.), Self-regulation of learning and performance: Issues and educational applications (25-44). Hillsdale, NJ: Lawrence Erlbaum Associates.

Meece, J. L., Anderman, E. M., \& Anderman, L. H. (2006). Classroom goal structure, student motivation, academic achievement. Annual Review of Psychology, 57, 487-503.

Meece, J. L., Glienke, B. B., \& Askew, K. (2009). Gender and motivation. In K. R. Wentzel \& A. Wigfield (Eds.), Handbook of motivation at school (411-431). NY: Routledge.

Meece, J. L., \& Holt, K. (1993). A pattern analysis of students' achievement goals. Journal of Educational Psychology, 85, 582-590.

Midgley, C., Kaplan, A., Middleton, M. J., Maehr, M. L., Urdan, T., Anderman, L., Anderman, E., \& Roese, R. (1998). The development and validation of scales assessing students' achievement goal orientation. Contemporary Educational Psychology, 23, 113-131.

Midgley, C., Maehr, M. L., Hruda, L. Z., Anderman, E., Anderman, L., Freeman, K. E., Gheen, M., Kaplan, A., Kumar, R., Middleton, M. J., Nelson, J., Roese, R., \& Urdan, T. (2000). Manual for the patterns of adaptive learning scales. University of Michigan.

Pintrich, P. R., \& De Groot, E. V. (1990). Motivational and self-regulated learning components of classroom academic performance. Journal of Educational Psychology, 82 (1), 33-40.

Schunk, D. H., Pintrich, P. R., \& Meece, J. L. (2008). Motivation in education. Theory, research, and applications. Upper Saddle River, NJ: Pearson/Merrill Prentice Hall.

Turner, J. C., \& Meyer, D. K. (2009). Understanding motivation in mathematics: What is happening in the classrooms? In K. R. Wentzel \& A. Wigfield (Eds.), Handbook of motivation at school (527552). NY: Routledge.

Wolters, C. A., Yu, S. L., \& Pintrich, P. R. (1996). The relation between goal orientation and students' motivational beliefs and self-regulated learning. Learning and Individual Differences, 8 (3), 211238.

Advised by Naglis Švickus, SMC “Scientia Educologica”, Lithuania

Received: January 20, 2012

Accepted: February 23, 2012

Inger Throndsen

Associate Professor, University of Oslo, P.O. Box 1099 Blindern, 0316 Oslo, Norway.

E-mail: inger.throndsen@ils.uio.no

Are Turmo

Associate Professor, University of Oslo, P.O. Box 1099 Blindern,

0316 Oslo, Norway.

E-mail: are.turmo@ils.uio.no 